\title{
Hastane Personelinin Atık Yönetimi ve Afetlerde Atık Yönetimi Konusunda Algı Düzeyi: Gümüşhane İli Örneği
}

The Level of Perception of Hospital Personnel on Waste Management and Waste Management in disasters: Case of Gümüşhane Province

\author{
Ümran Ayşen KÜÇÜK ${ }^{1}$, Afşin Ahmet KAYA ${ }^{2}$
}

\section{ÖZ}

Afet yönetiminin esas amaçları; toplumun karşı karşıya olduğu tehlikeleri analiz etmek, ortaya çıkabilecek zarar görülebilecek durumları tahmin etmek, ikincil afetlere neden olmayacak stratejiler geliştirme ve uygulama gibi çalışmalar gerçekleştirmektir. Afetler meydana geldikten sonra afet türüne bağlı olarak farklı çeşitlilikte atık meydana getirir. Afet atıkları yönetilemez ise ikincil bir afete sebep olabilir. Hastaneler ise afet anında aktif hizmet veren sağlık kuruluşlarıdır. Doğal olarak hastanelerin afet durumlarında daha fazla atı üretmesi kaçınılmazdır. Bu sebeple hastanelerin de olası bir afet durumuna yönelik bir atık yönetim stratejisinin olması gerekir. Atık yönetimi ise çalışanların atık konusunda tutum, farkındalık ve algıları ile verimli olabilir. Araştırma kapsamında hastane personeline anket uygulanmıştır. Anket üç bölümden oluşmaktadır. Birinci bölümde sosyo-demografik sorular bulunmaktadır. İkinci bölümü “Atık Yönetimi Farkındalık" soruları ve "Afetlerde Atık Yönetimi Farkındalık" soruları oluşturmaktadır. Üçüncü bölümde ise "Atık Yönetimi Tutum" soruları yer almaktadır. Çalışmanın verileri SPSS 21 paket programı ile analiz edilmiştir. Katılımcıların farkındalık düzeyi puan ortalaması yüksek, tutum düzeylerinin ise orta seviyelerde olduğu tespit edilmiştir. Katılımcıların farkındalık düzeyi puan ortalamasında cinsiyet ve yaş faktörlerinde anlamlı fark bulunmazken, çalışma süresi ve eğitim seviyesi faktörlerinde anlamlı sonuçlar bulunmuştur.

Anahtar Kelimeler: Afet, Afet Atık Yönetimi, Hastane Atık Yönetimi, Hastane Personeli

\begin{abstract}
The main objectives of disaster management are; to analyze the dangers faced by the society, to predict the situations that may be damaged by the event that may arise, to develop and implement strategies that will not allow secondary disasters. After disasters occur, different types of waste are generated depending on the type of disaster. If disaster waste is unmanageable, it can cause a secondary disaster. Hospitals, on the other hand, are health institutions that provide active service during disasters. Naturally, it is inevitable for hospitals to generate more waste in case of disasters. For this reason, hospitals should also have a waste management strategy for a possible disaster situation. Waste management, on the other hand, can be efficient with the employees' attitude, awareness and perception of waste. Within the scope of the research, a questionnaire was applied to the hospital staff. The questionnaire consists of three parts. The first part includes sociodemographic questions. The second part consists of Waste Management Awareness questions and Waste Management Awareness in Disasters questions. In the third part, there are Waste Management Attitude questions. The data of the study were analyzed with the SPSS 21 package program. It was determined that the awareness level of the participants was high, and their attitude level was medium. There is no significant difference in the mean score of the awareness level of the participants in terms of gender and age factors. Significant results were found in factors such as working time and education level.
\end{abstract}

Keywords: Disaster, Disaster Waste Management, Hospital Waste Management, Hospital Staff.

*Bu çalışma yüksek lisans tezinden türetilmiştir. Gümüşhane Üniversitesi Bilimsel Araștırma ve Yayın Etiği Kurulu'ndan etik izin (Karar No:30.10.2018-2018/8) alınmıştır.

${ }^{1}$ Öğr. Gör. Ümran Ayşen KÜÇÜK, Artvin Çoruh Üniversitesi, Acil Durum ve Afet Yönetimi Bölümü, Artvin Çoruh Üniversitesi Artvin Meslek Yüksekokulu, uaysenkucuk@artvin.edu.tr, ORCID:0000-0002-9799-7147

${ }^{2}$ Doç. Dr. Afşsin Ahmet KAYA, Acil Yardım ve Afet Yönetimi Bölümü, Gümüşhane Üniversitesi Gümüşhane Üniversitesi Sağlık Bilimleri Fakültesi,afsinakaya@gumushane.edu.tr, ORCID:0000-0003-2082-6478 


\section{GİRIȘ}

İnsan etkinlikleri daima atık üretmiştir. $\mathrm{Bu}$ durum insanların göçebe hayat yaşadığı ve insan nüfusunun az olduğu zamanlarda bir sorun olmamıştır. Fakat atıkların yönetilmesi kentleşme ve büyük şehirlerin büyümesiyle ciddi bir sorun haline gelmiştir. ${ }^{1}$ Yönetilemeyen atıklar, çevre sağlığı (sera gazı emülsiyonu, hava kirliliği vb.) ve halk sağlığ (solunum rahatsızlıkları, ishal, dang humması vb.) üzerinde olumsuz etkilere neden olmaktadır. ${ }^{2}$ Tarihte atıkların yönetilememesi ile ilgili olaylar da mevcuttur. Örneğin, Ortaçağ'da patojen atıklar ile kirlenmiş suya bağlı olarak salgınlar Avrupa'da nüfusun ciddi oranda azalmasına neden olmuştur. Ayrıca 19. yy. da ise atıklar sebebiyle kolera hastalığ baş göstermiştir. $^{1}$

Afetler ise hem yapıları hem de etkileri bakımından büyük miktarda yıkıntı ve atık oluşturabilir. ${ }^{3} \mathrm{Bu}$ atıkların sebep olduğu çevre sorunları da bize insanın yanı sira afetlerin de kirlilik kaynakları arasında olduğunu göstermektedir.

Afet atığ1, hem afetin doğrudan etkisi hem de yetersiz atık yönetimi nedeniyle afet sonrası dönemde oluşan atık olarak tanımlanmıştır. ${ }^{4}$

Afetlerin oluşturduğu atıklardan bazıları aşağıda sıralanmıştır.

- İnşaat ve yıkım kalıntıları,

- Sağlık hizmeti atıkları,

- İnsan ve hayvan cesetleri,

- Afetlerden etkilenen afet öncesi bertaraf tesislerinden kaynaklanan atıklar,

- Afet yerlerinden ve afet kamplarında meydana çıkan ambalaj atıkları ve diğer atıklar,

- Güç ve telefon şebekeleri parçaları (elektrik direkleri, transformatörler vb.),

- $\mathrm{Su}$ ve kanalizasyon dağıtım sistem parçaları,

- Sanayi ve atölyelerdeki kimyasallar (boyalar ve diğer hammaddeler),
- Yardım operasyonlarından gelen atıklar (amaç dışında kalan bağışlar),

- Hasarlı ulaşım araçları (tekneler, arabalar, otobüsler, bisikletler vb.),

- Patlamamış mühimmat

(kara mayınları),

- Evlerdeki temizlik malzemeleri,

- Bitkisel atık veya yeşil atık,

- Evlerdeki tehlikeli atık (soğutucu akışkanlar, yağlar, böcek ilaçları vb.),

- Yakıt ürünleri, endüstriyel ve toksik kimyasallar,

- Çürüyebilir atıklar (çürüyen gıdalar gibi),

- Geri dönüştürülebilir atıklar(plastik, metal vb.),

- Elektronik ve beyaz eşya gibi ev eşyaları ${ }^{4,5}$

Literatürde insan cesetlerinin atık olarak kabul edildiğine rastlansa da dinsel ve kültürel bakış açısı sebebiyle insan cesetlerini atık olarak kabul etmenin uygun olmadiğ 1 düşünülmektedir. ${ }^{4,5,6}$

Sağlık tehlikesi korkusundan ayrı olarak halk, anatomik atığın, fetüsler de dahil olmak üzere tanınabilir insan vücudunun görsel etkisine karşı duyarlıdır. Anatomik atıkları çöplüğe boşaltma gibi uygun olmayan şekilde atmak kabul edilebilir değildir. Müslüman kültürü ve diğer bazı kültürlerde, özellikle de Asya'da dini inançlar, insanlara ait vücut parçalarının afetzedenin ailesine iade edilmesini veya mezarlıklara gömülmesini gerektirir. ${ }^{6}$ Yani insan cesetleri, yerel kültür ve topluluklara saygilı şekilde hassas muameleye ihtiyaç duyar. ${ }^{4}$ Bu sebeple insan cesetleri afet atıkları grubunda yer almamalıdır. ${ }^{6}$

Afetlerden sonra ortaya çıkan atıkların fazla miktarda ve farklı çeşitlilikte olmasının nedeni afetlerin yapısı ve yıkıc1 özelliğinden kaynaklanmaktadır. ${ }^{7}$ Her bir afetin doğası farklılık gösterdiğinden atık verme süresi ve imha zorluğu da farklılık gösterir. ${ }^{8}$ 
Afetlerde ortaya çıkan atıklar mevcut yönetim tesislerini altüst edebilir niteliktedir. Ayrıca atıklar acil müdahale, kurtarma faaliyetlerini ve iyileşme sürecini de etkileyebilir. Bu sebeple kötü yönetilen atıklar çevre sağlığı ve halk sağlığ düzeyde risk yaratabilir. ${ }^{3}$

Afetlerde meydana gelen atıklar insan sağlığına, biyolojik kaynaklara, kimyasal kaynaklara ve fiziksel kaynaklara karşı bir risk oluşturmaktadır. ${ }^{9}$ Afet atıklarının riskleri kimyasal, biyolojik, fiziksel ve çevresel olmak üzere 4 gruba ayrılmıştır. ${ }^{10}$

\section{Kimyasal Riskler}

$\mathrm{Bu}$ risk grubu yapısında kimyasal madde bulunan atıkları kapsar;

- Böcek ilac1, yağ ve asit gibi kirletici maddeler ile doğrudan cilt teması,

- Tehlikeli kimyasalların veya böcek ilac1, toz, asbest lifleri gibi ürünlerin solunmas1,

- Atık sızıntı suyu ile kirlenmiş yüzey ve yeraltı suyunun kullanılması,

- Atıktaki kimyasal maddelerden kaynaklanan koku kaynaklı rahatsızlıklar. ${ }^{10}$

\section{Biyolojik Riskler} kapsar;

$\mathrm{Bu}$ risk grubu biyolojik yapılı atıkları

- Ciltle temas/biyolojik atıkların yutulmas1,

- Sağlık hizmeti atıklarına doğrudan maruz kalma,

- Atıkta ya da yakınında toplanan hayvanlardan hastalık vektörleri,

- Hayvanlar ya da böcekler tarafindan yayılan hastalıklar,

- Atıklardan beslenen ve atıkların çektiği böcek, kuş ve kemirgenlerin beslenmesi ${ }^{10}$

\section{Fiziksel Riskler}

$\mathrm{Bu}$ risk grubu atıkların fiziksel olarak sebep olduğu riskleri kapsar;
- $\quad$ Bir yolun kenarına itilmiş büyük moloz yığınları gibi binaların ve diğer yapıların yanı sıra atık yığınlarının çökmesi,

Sağlık hizmeti atıklarının genel evsel atıklarla karıştırıldığı yerlerde bulunan atıktaki keskin nesnelerden kaynaklanan kesikler ve siyrıklar.

- $\quad$ Atık yığınlarında kontrolsüz yanginlar,

- Atıkların toplanması, taşınması ve bırakılması nedeniyle araç kazaları,

- Çöplerin rüzgâr gibi nedenlerden dağılması 10

\section{Çevresel Riskler}

$\mathrm{Bu}$ risk grubu atıkların çevreye verdiği riskleri kapsar;

- Toprakları kirleten, insanları ve hayvanları için tehlikeli hale getiren ve/ veya tarım için uygun olmayan atık,

- Atıklar ile temas eden sizintı su varlığ 1

- İnsan ve hayvanlara risk oluşturabilecek organik atıkların ayrışmasından kaynaklanan atık gaz, böcek istilası,

Atıklarla beslenen kemirgen ve

- $\quad$ Bir bölgeyi etkileyebilecek rüzgârdan ve dalga ile taşınan çöplerin varlığı olarak belirlenmiştir. ${ }^{10}$

Yaşanan afetler sonucu atıkların önemli bir problem olduğu bazı çalışmalarda da rapor edilmiştir. 2004 Hint Okyanusu'nda meydana gelen deprem sonucu ortaya çıkan tsunami dalgaları; tıbbi atıkları, tehlikeli atıkları, bitki örtüsü, foseptiklerden gelen belediye atıkları, enkazları ve yardım operasyonlarından kaynaklanan atıkları oluşturmuştur. Bu atıklar deniz çevresine, yer altı su kaynaklarına, sağlık tesislerine, insan sağlığına yönelik ciddi tehdit meydana getirmiştir. ${ }^{11}$ Ayrıca bu tehditler içerisinde acil durumlarda sağlık kurumlarının oluşturduğu atıklar da (tedavi için kullanılan kontamine malzemeler) bulunmaktadır. $^{12}$ 
Afet atıklarının yönetilememesinin nedeni atık yönetiminin genellikle yetersiz düzeyde planlanması ve personel eğitiminin eksik olmasidir. ${ }^{13}$

Hastanelerin bir yandan sağlığ iyileştirmek için sağlik hizmeti vermesi bir yandan da atık oluşturarak çevresel sağlığa zarar vermesi üzerinde durulması gereken önemli bir konudur. ${ }^{14}$ Sağlık kurumlarının oluşturduğu atıklar çevresel sorunlara ek olarak hastanenin hizmet kalitesini düşürmekte ve hastane bünyesine ekonomik külfet olmaktadır. ${ }^{15} \mathrm{Bu}$ sebeple sağlık kurumları ulusal politika ve yasal çerçeve oluşturup, personeli eğitimli hale getirip atıklarını çevreye ve sağlığa uygun koşulda yöneterek topluma örnek olmalıdır. ${ }^{16}$

Sağlık hizmetleri atıklarının yönetimi, atık çeşitliliğinden dolayı birden fazla yönetmelik dâhilinde yürütülür. $\mathrm{Bu}$ da hâlihazırda zor olan atık yönetimini zorlaştırmaktadır. Afet ve acil durumlarda ise atık üretimi artacağından sağlık kurumlarının atıkları yönetmekte zorlanacağı aşikârdır. Hastanelerin olağan ve olağan dışı durumlardaki atıkları uygun yönetilemediğinde halk sağlığ 1 , maddi kayıp ve her türlü sürecin aksaması gibi sorun yaşanmaktadır. Ayrıca atıkların yönetilememesinden kaynaklı bir acil durum ya da bir afet olayı ile karşılaşma riski de bulunmaktadır. Atıkların yanlış yönetim sonucunda karşılaşılacak acil durumlara ya da afetlere, küçük veya büyük salgınlar, atık kaynaklı yangınlar ya da atık kaynaklı patlamalar vb. örnek verilebilir. Afet durumunda çıkan atıkların ikincil afete sebep olacağ1 gibi afet olmayan zamanlarda da atıkların kendi başına bir afet ya da acil durum boyutuna gelme ihtimali göz önünde bulundurulmalıdir.

Hastanelerin olası bir afet durumunda atık yönetim stratejisi olması gerekir. Hastane personeli atık yönetiminin uygun ve verimli yürütülmesini sağlayacak bireylerdir. Çünkü atık yönetimi sadece yöneticilerin değil, çalışanların da aktif olarak rol aldığı bir davranış bütününden oluşmaktadır. $\mathrm{Bu}$ çalışma, hastanelerin afetlerde atık yönetimi ve olağan atık yönetim süreci konusunda gelecekteki kapsamlı araştırmalar için bir çerçeve oluşturacağı öngörülerek hazırlanmıştır.

Hastanelerin afet durumundaki atık yönetimi ile ilgili yapılan araştırmalar sonucunda literatürde boşluk olduğu fark edilmiştir. Günümüzde karşı karşıya kaldığımız atık problemini yalnızca hukuki çerçeveler ile sınırlandırıp başarılı olmayı beklemek doğru değildir. Bunun için toplumun her kesiminin atıklar konusunda farkındalığa sahip olması gerekmektedir. Ayrıca sahip olunan farkındalık da yeterli olmayacaktır. Bireylerin farkındalıklarını tutumları ile birlikte olumlu olarak desteklemesi gerekir. Böylece atıklar günümüzde bir problem olmaktan çıkabilir. $\mathrm{Bu}$ çalışmada hastane personelinin hastane atık yönetimi ve afetlerde atık yönetimi konusunda farkındalık ve tutum düzeylerinin ölçülmesi hedeflenmiştir.

\section{MATERYAL VE METOT}

\section{Araştırmanın Türü}

Araştırma, tanımlayıcı tipte bir çalışmadır.

\section{Araştırmanın Yeri ve Zamanı}

Bu araştırma 2018-2019 yılları arasında Gümüşhane Devlet Hastanesi ve diğer 5 ilçe (Kelkit, Köse, Kürtün, Şiran ve Torul) bünyesinde faaliyet gösteren devlet hastanelerinde yapılmıştır. Araştırmanın anket uygulama tarihi ise 12.11.201814.12.2018 tarihleri arasıdır.

\section{Araştırmanın Evren ve Örneklemi}

Araştırmanın evrenini 2018-2019 yılları arasında Gümüşhane Devlet Hastanesi ve 5 ilçe devlet hastanesinde aktif olarak görev yapan 356 personel oluşturmaktadır. Kat1lımc1lar afetlerde aktif müdahalede bulunacak idari birim, doktor, hemşire ve yardımcı sağlık personelidir. Çalışmaya hastane bünyesinde temizlik hizmetleri çalışanları, kantin işletmecileri ve yemekhane çalışanları dâhil edilmemiştir. Uygulanan 
anketler yüz yüze uygulanmış olup katılım için gönüllülük esas alınmıştır. Katılımcılar arasında 61 doktor, 153 hemşire, 125 yardımcı sağlık personeli ve 17 idari birim personeli bulunmaktadır. Araştırmada ek olarak sadece yöneticilerin dâhil olduğu 'Kurumsal Atık Yönetim Kontrol Listesi' için 15 yönetici kapsam içerisindedir.

\section{Veri Toplama Araçları}

Araştırmada veri toplama aracı olarak Elgitait tarafindan (2013) yilında yazılan doktora tezinde kullanilan anket formu kullanılmıştır. ${ }^{17}$ Anket soruları ülke koşullarına uygun olarak düzenlenmiştir. Ülke koşullarına uygun görülmeyen bazı sorular uzman görüşü alınarak çıkartılmış yerlerine literatür taraması yapılarak soru eklenmiş ve güvenilirlik analizi yapılmıştır. Anket 3 bölümden oluşmaktadır. Birinci bölümde sosyo-demografik bilgiler (10 soru), ikinci bölümde atık yönetimi farkındalık soruları (10 soru) ve afetlerde atık yönetimi farkındalık soruları (11 soru) üçüncü bölümde ise afetlerde atık yönetimi tutum (12 soru) soruları bulunmaktadır. Ayrica sadece yöneticilere sorulan 'Kurumsal Atık Yönetim Kontrol Listesi' kullanılmıştır. Ülkemizde ortaöğretimden sonra sağlik personeli olarak çalışan kişilerin de varlığı sebebiyle sosyodemografik bilgilerde yer alan yaş faktöründe homojen bir dağılım yapılmamıştır.

Katılımcıların farkındalık düzeyi puan ortalamaları 10 soru üzerinden, toplamda 100 puanlık bir farkındalık düzeyi olacak şekilde araştırmacılar tarafından tasarlanmıştır. Farkındalık sorularından her evet seçeneği için 10 puan, hayır seçeneği için 0 puan verilmiştir. Tablo 1'de farkındalık düzeyi puan skalası bulunmaktadır.

Tablo 1. Farkındalık Düzeyi Puan Skalası

\begin{tabular}{ll}
\hline Puan & Düzeyi \\
\hline $0-20$ & Çok Düşük \\
\hline $21-40$ & Düşük \\
\hline $41-60$ & Orta \\
\hline $61-80$ & Yüksek \\
\hline $81-100$ & Çok Yüksek \\
\hline
\end{tabular}

Farkındalık puan düzeyi; ' 0 -20' olan çok düşük, '21-40' olan düşük, '41-60' olan orta, '61-80' olan yüksek ve '81-100' olan çok yüksek olarak değerlendirilmiştir.

Tablo 2'de yer alan skala ise tutum düzeyini belirlemeye yönelik hazırlanan tutum düzeyi puan skalasıdır.

Tablo 2. Tutum Düzeyi Puan Skalası

\begin{tabular}{cl}
\hline Puan & Düzeyi \\
\hline 1 & $\begin{array}{l}\text { Kesinlikle } \\
\text { Katılmiyorum }\end{array}$ \\
\hline 2 & Katılmiyorum \\
\hline 3 & Kararsızım \\
\hline 4 & Katıliyorum \\
\hline 5 & $\begin{array}{l}\text { Kesinlikle } \\
\text { Kat1liyorum }\end{array}$ \\
\hline
\end{tabular}

Tablo 2'de belirtildiği üzere, tutum düzeyleri ' 1 ' kesinlikle katılmıyorum, '2' katılmıyorum, '3' kararsızım, '4' katıliyorum ve ' 5 ' kesinlikle katıliyorum şeklinde değerlendirilmiştir.

\section{Verilerin Toplanması}

Araştırmanın kapsamında Gümüşhane ili merkez ilçe dâhil olmak üzere diğer 5 ilçedeki devlet hastaneleri seçilmiştir. İl ve ilçelerde görev yapan ve afetlerde aktif müdahalede bulunacak idari birim, doktor, hemşire ve yardımcı sağlık personeli olarak görev yapan 356 personele ulaşılarak atık yönetimi ve afetlerde atık yönetimi konusunda farkındalık ve tutum anketi uygulanmıştır. Ayrıca yönetici pozisyonundaki katılımcilara "Kurumsal Kontrol Listesi', uygulanmıştır. Bir katılımcının yüz yüze anket görüşmesinin ortalama 10-15 dakika arasında olduğu gözlemlenmiştir. Yöneticilere ek olarak yapılan 'Kurumsal Atık Yönetim Kontrol Listesi' ise ortalama 4-6 dakika sürmüştür.

\section{Verilerin Değerlendirilmesi}

Araştırma analizlerinde SPSS 21.0 paket programı kullanılarak tanımlayıcı istatistiksel metotlar (ortalama, standart sapma vb.) ve güvenilirlik analizi için Reliability Analysis 
kullanılmıştır. Anlamlılık değeri $\mathrm{p}<0,05$ düzeyinde değerlendirilmiş̧tir.

\section{Araştırmanın Etik Yönü}

Araştırmanın yürütülebilmesi için Gümüşhane Üniversitesi Bilimsel Araştırma ve Yayın Etiği Kurulu'ndan gerekli onay
(Karar No: 30.10.2018-2018/8) alınmıştır. Araştırmanın gerçekleştirildiği Gümüşhane İl Sağlık Müdürlüğü'nden Kurum izni (02.11.2018 tarih ve 49229421-044 say1) alınmıştır. Literatürdeki kaynaklar doğrultusunda anket soruları yazarlar tarafından düzenlenmiştir.

\section{BULGULAR VE TARTIŞMA}

33 soru üzerinden güvenirlik analizine tabi tutulması sonucu çalışmanın Cronbach's Alfa değeri 0,765 olarak bulunmuştur. Genel olarak ölçek geliştirme uyarlama çalışmalarında kullanılan Cronbach's Alfa değerinin en az 0,700 ve üzeri olması gerektiği kabul edilmektedir. ${ }^{18}$ Sonuç olarak veri toplama aracı olarak kullandığımız araç güvenilirdir.

Araştırma dâhiline alınan katılımcıların; \%66,9'unun kadın ( $\mathrm{n}=238), \%$ 49,4'ünün evli $(n=176)$ olduğu görülmektedir. Kat1lımcıların yaş gruplarına bakıldığında ise; \%58,7'sinin 18-30 yaş aralığında $(n=209), \% 27,0$ 'ının 31 40 yaş aralığında $(n=96), \% 13,8$ 'inin 41-50 yaş aralığında $(\mathrm{n}=49), \% 0,6$ 'sının ise 51-60 yaş aralığında $(\mathrm{n}=2)$ olduğu görülmektedir (Tablo 3).

Katılımcıların çalışma yılına göre değerlendirilmesinde; \%53,1'inin 0-5 y1l arasinda $\quad(n=189), \% 25,6$ 'sinin $\quad 6-10 \quad$ yil aralığında $(\mathrm{n}=91), \% 13,8$ 'inin 11-15 yıl arasinda $(\mathrm{n}=49), \% 3,1$ 'inin 16-20 y1l arasinda $(n=11), \% 4,5$ 'inin 21 y1l ve üzeri $(n=16)$ olduğu görülmektedir (Tablo 3).

Katılımcıların eğitim durumu değerlendirildiğinde, \%10,1 lise düzeyinde $(\mathrm{n}=36), \% 22,5$ 'inin ön lisans düzeyinde $(\mathrm{n}=80), \quad \% 53,9$ 'sinin lisans düzeyinde (n=192), \%9,3'ünün yüksek lisans düzeyinde $(\mathrm{n}=33)$ ve $\% 4,2$ 'sinin doktora düzeyinde $(n=15)$ olduğu görülmektedir (Tablo 3$)$.

Katılımcılar kurumdaki görevlerine göre değerlendirildiğinde ise, $\% 4,8$ 'inin idari birim $(\mathrm{n}=17), \quad \% 17,1$ 'inin doktor $\quad(\mathrm{n}=61)$, \%43,0'ünün hemşire $(\mathrm{n}=153), \% 35,1$ 'inin yardımcı sağlık personeli $(n=125)$ olduğu belirtilmiştir (Tablo 3 ).

Katılımcıların hangi hastanede çalıștıkları değerlendirildiğinde; \%46,9'unun Gümüşhane Devlet Hastanesi $(\mathrm{n}=167)$, \%26,4'ünün Kelkit Devlet Hastanesi ( $\mathrm{n}=94$ ), $\% 9,0$ 'ının Şiran Devlet Hastanesi $(n=32)$, $\% 6,2$ 'sinin Torul Devlet Hastanesi $(\mathrm{n}=22)$, $\% 5,1$ 'inin Kürtün Devlet Hastanesi $(\mathrm{n}=18)$, \%6,5'inin Köse Devlet Hastanesi ( $\mathrm{n}=23$ ) olduğu görülmektedir (Tablo 3).

Kat1lımcılara sorulan 'Atık yönetimi eğitimi aldınız mı?' sorusuna \%57,9'unun evet $(n=206)$ cevabını verdiği görülmüștür. 'Afetlerde atık yönetimi eğitimi aldınız mı?' sorusuna \%27,2'si evet $(n=97)$ cevabını verdiği görülmüştür. Katılımcıların 'Afet eğitimi aldınız mı?' sorusuna verdikleri cevaplar değerlendirildiğinde ise \%48,6'sının evet $(n=173)$ cevabını verdiği görülmüştür (Tablo 3). 


\section{Tablo 3. Demografik Bilgiler}

\begin{tabular}{|c|c|c|c|}
\hline Özellik & Dağılım & Sayı & Yüzde (\%) \\
\hline \multirow[b]{2}{*}{ Cinsiyet } & Kadın & 238 & 66,9 \\
\hline & Erkek & 118 & 33,1 \\
\hline \multirow{2}{*}{ Medeni Durum } & Evli & 176 & 49,4 \\
\hline & Bekâr & 180 & 50,6 \\
\hline \multirow{4}{*}{ Yaş } & $18-30$ & 209 & 58,7 \\
\hline & $31-40$ & 96 & 27,0 \\
\hline & $41-50$ & 49 & 13,8 \\
\hline & $51-60$ & 2 & 0,6 \\
\hline \multirow{5}{*}{ Çalışma Yılı } & $0-5 Y_{11}$ & 189 & 53,1 \\
\hline & 6-10 Yil & 91 & 25,6 \\
\hline & 11-15 Y1l & 49 & 13,8 \\
\hline & $16-20 \mathrm{Y}_{11}$ & 11 & 3,1 \\
\hline & 21 Y1l ve üzeri & 16 & 4,5 \\
\hline \multirow{5}{*}{ Eğitim Durumu } & Lise & 36 & 10,1 \\
\hline & Ön lisans & 80 & 22,5 \\
\hline & Lisans & 192 & 53,9 \\
\hline & Yüksek Lisans & 33 & 9,3 \\
\hline & Doktora & 15 & 4,2 \\
\hline \multirow{4}{*}{ Kurumdaki Görevi } & İdari Birim & 17 & 4,8 \\
\hline & Doktor & 61 & 17,1 \\
\hline & Hemşire & 153 & 43,0 \\
\hline & Yardımcı Sağlık Personeli & 125 & 35,1 \\
\hline \multirow{6}{*}{$\begin{array}{l}\text { Hangi Hastanede } \\
\text { Çalışıyorsunuz? }\end{array}$} & Gümüşhane Devlet Hastanesi & 167 & 46,9 \\
\hline & Kelkit Devlet Hastanesi & 94 & 26,4 \\
\hline & Şiran Devlet Hastanesi & 32 & 9,0 \\
\hline & Torul Devlet Hastanesi & 22 & 6,2 \\
\hline & Kürtün Devlet Hastanesi & 18 & 5,1 \\
\hline & Köse Devlet Hastanesi & 23 & 6,5 \\
\hline \multirow{2}{*}{$\begin{array}{l}\text { Atık Yönetimi Eğitimi } \\
\text { Aldınız Mı? }\end{array}$} & Evet & 206 & 57,9 \\
\hline & Hayır & 150 & 42,1 \\
\hline \multirow{2}{*}{$\begin{array}{l}\text { Afetlerde Atık Yönetimi } \\
\text { Eğitimi Aldınız Mı? }\end{array}$} & Evet & 97 & 27,2 \\
\hline & Hayır & 259 & 72,8 \\
\hline \multirow{2}{*}{ Afet Eğitimi Aldınız Mı? } & Evet & 173 & 48,6 \\
\hline & Hayır & 183 & 51,4 \\
\hline
\end{tabular}


Araştırma sonucunda elde ettiğimiz verilere göre katılımcıların farkındalık düzeyi puan ortalamas1 74,24 $\pm 16,606$ olarak bulunmuştur. Tablo 1'de yer verdiğimiz skalaya göre 74,24 'lük puan ortalaması yüksek düzey olarak belirlenmiştir. Katılımcıların farkındalık düzeyi puan ortalamaları çalışma sürelerine göre değerlendirildiğinde istatistiksel olarak anlamlı fark bulunmuştur $(\mathrm{p}<0,05)$. Çalışma süresi 21 yıl ve üzeri olan katılımcıların farkındalık düzeyi puan ortalaması $83,75 \pm 16,683$ olduğu saptanmıştır. $\mathrm{Bu}$ farkındalık düzeyi puan ortalaması Tablo 1'deki skalaya göre çok yüksek düzey olarak bulunmuştur. Sonuç olarak çalışma süresi 21 yıl ve üzeri olan katılımcıların farkındalık düzeyi puan ortalamaları diğer katılımcılara göre daha yüksektir. Katılımcıların farkındalıklarının fazla olmasının nedeni, çalışma süresi, iş deneyimleri ve tecrübeleri ötürü olduğu düşünülebilir.

Katılımcıların farkındalık düzeyi puan ortalamaları, eğitim durumlarına göre değerlendirildiğinde, istatistiksel olarak anlamlı fark bulunmuştur $(\mathrm{p}<0,05)$. Doktora eğitim durumuna sahip olan katılımcıların farkındalık düzeyi puan ortalamaları $86,66 \pm 13,451$ olduğu görülmüştür. Doktora eğitim seviyesine sahip olan katılımcıların farkındalık düzeyi puan ortalamaları diğer katılımcılara göre daha yüksektir.

Katılımcıların farkındalık düzeyi puan ortalamaları, atık yönetimi eğitim durumlarına göre değerlendirildiğinde, istatistiksel olarak anlamlı fark bulunmuştur $(\mathrm{p}<0,05)$. Farkındalık düzeyi puan ortalamaları, atık yönetimi eğitimi alanların $75,97 \pm 16,193$ olduğu görülmüştür. Atık yönetimi eğitimi alan katılımcıların farkındalık düzeyi puan ortalamaları atık yönetimi eğitimi almayan katılımcılardan daha yüksek olduğu bulunmuştur. Bu durum atık yönetimi eğitimi alan katılımcıların, aldıkları eğitimin farkındalıklarını etkilediği düşünülmektedir. Elgitait (2013), Libya ve Birleşik Krallık'taki hastane personelinin hastane atı yönetimi algılarını ve uygulamalarını karşılaştırma yaptığ 1 çalışmasında; eğitimin, hastane çalışanlarının tutumlarını ve farkındalığını arttırdığı görülmüştür. ${ }^{17}$ Çalışmamızda da aynı doğrultuda atık yönetimi eğitimi, afetlerde atık yönetimi eğitimi ve afet eğitimi alan personellerin farkındalık düzeylerinin daha yüksek olduğu görülmüştür.

Katılımcıların farkındalık düzeyi puan ortalamaları, afetlerde atık yönetimi eğitimi durumlarına göre değerlendirildiğinde, istatistiksel olarak anlamlı fark bulunmuştur $(p<0,05)$. Afetlerde atık yönetimi eğitimi alan katılımcıların farkındalık düzeyi puan ortalamaları 78,24 $\pm 16,457$ iken almayanların $72,74 \pm 16,442$ olduğu görülmüştür. Afetlerde atık yönetimi eğitimi alan katılımcıların farkındalık düzeyi puan ortalamaları diğerlerine göre daha yüksektir. Bunun sebebi ise afetlerde atık yönetimi eğitimi içeriğinin atıklar konusunda farkındalık düzeyini olumlu etkilediği düşünülebilir.

Katılımcıların farkındalık düzeyi puan ortalamaları, afet eğitimi durumlarına göre değerlendirildiğinde, istatistiksel olarak anlamlı fark bulunmuştur $(\mathrm{p}<0,05)$. Afet eğitimi alan katılımcıların farkındalık düzeyi puan ortalamaları $77,80 \pm 15,620$ olduğu görülmüş̧ür. Afet eğitimi alan katılımcıların farkındalık puan düzeyi ortalamaları diğerlerine göre daha yüksektir. Bu sonuç alınan afet eğitimlerinin bireylere atıklar konusunda farkındalık kazandırdığı şeklinde yorumlanmiştır.

Katılımciların tutum düzeyi puan ortalamalar1 $3,88 \pm 0,629 \quad$ 'kararsizım' kategorisi olarak bulunmuştur (Tablo 2). Bu sonuç, personelin sahip olduğu bilgiden emin olmadığı yani kararsız olduğu şeklinde yorumlanmıştır.

Katılımciların tutum düzeyi puan ortalamaları yaş durumlarına göre değerlendirildiğinde, istatistiksel olarak aralarında anlamlı farklılık bulunmuştur $(\mathrm{p}<0,001)$. Katılımciların tutum düzeyi puan ortalamaları yaş ilerledikçe azalmaktadır. 1830 yaş aralığındaki katılımcıların tutum düzeyi puan ortalamaları $3,97 \pm 0,606$ olduğu görülmüştür. Katılımcılar arasında tutum düzeyi puan ortalamaları en yüksek olan 1830 yaş grubudur. $\mathrm{Bu}$ yaş grubunun tutum konusunda çevresel olarak daha dikkatli ve 
güncel değişikliklerden haberdar olduklarından dolayı tutum düzeylerinin yüksek olabileceği düşünülmektedir.

Katılımciların tutum düzeyi puan ortalamaları cinsiyet, medeni durum, çalışma süresi, eğitim durumu, kurumdaki görevi, afetlerde atık eğitimi alma durumu ve afet eğitimi alma durumu gibi değişkenler ile değerlendirildiğinde, istatistiksel olarak bir farklılık bulunmamıştır. Katılımcıların hangi hastanede görev aldığ 1 ve atık eğitimi alma durumlarına göre değerlendirildiğinde ise aralarında istatistiksel olarak anlamlı farklılık bulunmuştur fakat varyansların homojen olarak dağılmadığı saptanmıştır.

Tablo 4. Farkındalık Düzeyi Puan Ortalaması ile Tutum Düzeyi Puan Ortalaması Arasında Korelasyon Analizi

\begin{tabular}{|c|c|c|c|}
\hline & & $\begin{array}{l}\text { Farkındalık } \\
\text { Düzeyi } \\
\text { Puan } \\
\text { Ortalaması }\end{array}$ & $\begin{array}{l}\text { Tutum } \\
\text { Düzeyi } \\
\text { Puan } \\
\text { Ortalam } \\
\text { ası }\end{array}$ \\
\hline \multirow{3}{*}{$\begin{array}{l}\text { Farkındalık } \\
\text { Düzeyi } \\
\text { Puan } \\
\text { Ortalaması }\end{array}$} & Pearson & 1 & ,196** \\
\hline & Sig. & & ,000 \\
\hline & $\mathrm{n}$ & 356 & 356 \\
\hline \multirow{3}{*}{$\begin{array}{l}\text { Tutum } \\
\text { Düzeyi } \\
\text { Puan } \\
\text { Ortalaması }\end{array}$} & Pearson & ,196** & 1 \\
\hline & Sig. & ,000 & \\
\hline & $\mathrm{n}$ & 356 & 356 \\
\hline
\end{tabular}

Tablo 4'te görüldüğü üzere farkındalık düzeyi puan ortalaması ile tutum düzeyi puan ortalaması arasında pozitif yönde doğrusal bir ilişki olduğu görülmüştür. Tutum düzeyi ve farkındalık arasındaki ilişki $\mathrm{p}<0,01$ düzeyinde anlamlıdır. $\mathrm{Bu}$ durum, farkındalık düzeyi puan ortalaması ile tutum düzeyi puan ortalaması arasında birlikte artış ve azalış gösterdiği şeklinde yorumlanmaktadır. Ayrıca araştırmada ulaştığımız anlamlı sonuçlara göre eğitim düzeyi farkındalık düzeyini olumlu yönde etkilediği görülmüştür. Sonuç olarak afet eğitiminin tutum üzerinde olumlu etkisi vardir.

Katılımcıların "Geri dönüşüm ve azaltılmış atık miktarını dikkate almayı amaçlayan bir satın alma politikası uyguluyor musunuz?" sorusuna verdikleri cevaplar değerlendirildiğinde, \%66,7'si evet $(\mathrm{n}=10)$ cevabını vermişlerdir. Katılımcıların " $\mathrm{Bu}$ satın alma politikasını başlattığınızdan beri atık miktarındaki kilo kaybını tahmin ettiniz mi?" sorusuna verdikleri cevaplar değerlendirildiğinde, \%46,7'si evet $(n=7)$ cevabını vermişlerdir (Tablo 5).

Katılımcıların "Hastanenizin özel bir atık yönetim planı var mı?" sorusuna verdikleri cevaplar değerlendirildiğinde, \%93,3'ü evet $(n=14)$ cevabını vermişlerdir. Katılımcıların "Bu özelleştirilmiş atık planı mevcut olan en iyi uygulama ile uyumlu olarak geliştirildi mi?" sorusuna verdikleri cevaplar değerlendirildiğinde, \%73,3'ü evet $(n=11)$ cevabını vermişlerdir (Tablo 5).

Katılımcıların "Hastanenizin atı yönetiminde geri dönüşümün iyi temsil edildiğini düşünüyor musunuz?" sorusuna verdikleri cevaplar değerlendirildiğinde, $\% 60,0$ '1 evet $(\mathrm{n}=9)$ cevabını vermişlerdir. Katılımcıların "Seçilmiş atık politikanızı yansıtan, net atık yönetimi sorumluluklarını, tüm hastane çalışanlarının iş tanımlarına her zaman ekliyor musunuz?" sorusuna verdikleri cevaplar değerlendirildiğinde, \%60,0'1 evet $(\mathrm{n}=9)$ cevabını vermişlerdir (Tablo 5).

Katılımcıların "Atık yönetim politikanızı güvenilir ve güncel olarak değerlendiriyor musunuz?" sorusuna verdikleri cevaplar değerlendirildiğinde, \%80,0'1 evet $(\mathrm{n}=12)$ cevabını vermişlerdir. Katılımcıların "2015, 2016, 2017 y1llarının her birinin toplam atık ağırlık kayıtlarını tutuyor musunuz?" sorusuna verdikleri cevaplar değerlendirildiğinde, \%100,0'ü evet $(n=15)$ cevabını vermişlerdir (Tablo 5). 


\section{Tablo 5. Yöneticilerin Kurumsal Atık Yönetim Kontrol Listesi}

\begin{tabular}{|c|c|c|c|c|}
\hline \multirow{2}{*}{$\begin{array}{l}\text { YÖNETİCILERİN KURUMSAL ATIK YÖNETİM KONTROL } \\
\text { LİSTESİ }\end{array}$} & \multicolumn{2}{|c|}{ Evet } & \multicolumn{2}{|c|}{ Hayır } \\
\hline & $\mathbf{N}$ & $\%$ & $\mathbf{N}$ & $\%$ \\
\hline $\begin{array}{l}\text { 1. Geri dönüşüm ve azaltılmış atık miktarını dikkate } \\
\text { almayı amaçlayan bir satın alma politikası uyguluyor } \\
\text { musunuz? }\end{array}$ & 10 & 66,7 & 5 & 33,3 \\
\hline $\begin{array}{l}\text { 2. Bu satın alma politikasını başlattığınızdan beri atık } \\
\text { miktarındaki kilo kaybını tahmin ettiniz mi? }\end{array}$ & 7 & 46,7 & 8 & 53,3 \\
\hline 3. Hastanenizin özel bir atık yönetim planı var mı? & 14 & 93,3 & 1 & 6,7 \\
\hline $\begin{array}{l}\text { 4. Bu özelleştirilmiş atık planı mevcut olan en iyi } \\
\text { uygulama ile uyumlu olarak geliştirildi mi? }\end{array}$ & 11 & 73,3 & 4 & 26,7 \\
\hline $\begin{array}{l}\text { 5. Hastanenizin atık yönetiminde geri dönüşümün iyi } \\
\text { temsil edildiğini düşünüyor musunuz? }\end{array}$ & 9 & 60 & 6 & 40 \\
\hline $\begin{array}{l}\text { 6. Seçilmiş atık politikanızı yansıtan, net atık yönetimi } \\
\text { sorumluluklarını, tüm hastane çalışanlarının iş } \\
\text { tanımlarına her zaman ekliyor musunuz? }\end{array}$ & 9 & 60 & 6 & 40 \\
\hline $\begin{array}{l}\text { 7. Atık yönetim politikanızı güvenilir ve güncel olarak } \\
\text { değerlendiriyor musunuz? }\end{array}$ & 12 & 80 & 3 & 20 \\
\hline $\begin{array}{l}\text { 8. 2015,2016, } 2017 \text { yıllarının her birinin toplam atık ağırlık } \\
\text { kayıtlarını tutuyor musunuz? }\end{array}$ & 15 & 100 & 0 & 0 \\
\hline $\begin{array}{l}\text { 9. Sözleşmede ve iş tanımında, atık toplama } \\
\text { personelinizin toplama sırasında kişisel koruyucu } \\
\text { donanım (eldiven, maske,kıyafet vb.) giymesini } \\
\text { zorunlu kilıyor musunuz? }\end{array}$ & 15 & 100 & 0 & 0 \\
\hline $\begin{array}{l}\text { 10. Satın alma politikanıza, daha güvenli ve çevre dostu } \\
\text { ürünler satın almayı bir kural haline getiriyor } \\
\text { musunuz? }\end{array}$ & 10 & 66,7 & 5 & 33,3 \\
\hline $\begin{array}{l}\text { 11. İş sözleşmelerinizde atık toplama işlemlerinde } \\
\text { personelinizin bulaşıcı hastalıklara ( Hepatit B vb.) } \\
\text { karşı aşılanmasını zorunlu kılıyor musunuz? }\end{array}$ & 15 & 100 & 0 & 0 \\
\hline $\begin{array}{l}\text { 12. Kesici ve delici tıbbi atık kutuları ile tıbbi atık } \\
\text { torbalarının en fazla } 3 / 4 \text { oranında olmasına dikkat } \\
\text { ediyor musunuz? }\end{array}$ & 15 & 100 & 0 & 0 \\
\hline $\begin{array}{l}\text { 13. Tibbi atıklar ile evsel nitelikli atıkların aynı araca } \\
\text { yüklenmemesine ve birlikte tașınmamasına dikkat } \\
\text { ediyor musunuz? }\end{array}$ & 15 & 100 & 0 & 0 \\
\hline $\begin{array}{l}\text { 14. Kurumdaki atık miktarına ilişkin tutulan raporları } \\
\text { yılsonunda valiliklere bildiriyor musunuz? }\end{array}$ & 10 & 66,7 & 5 & 33,3 \\
\hline $\begin{array}{l}\text { 15. Evsel ve tıbbi atık depo kapıları kullanımları dışında } \\
\text { daima kapalı ve kilitli tutulmasını kontrol ediyor } \\
\text { musunuz? }\end{array}$ & 15 & 100 & 0 & 0 \\
\hline 16. Evsel atık içeriklerini kontrol eder misiniz? & 13 & 86,7 & 2 & 13,3 \\
\hline $\begin{array}{l}\text { 17. Renk kodlu atık ayırma kılavuzu gibi materyaller } \\
\text { kullanıyor musunuz? }\end{array}$ & 12 & 80 & 3 & 20 \\
\hline $\begin{array}{l}\text { 18. Hastane atıklarını azaltmak için hastanenize uygun bir } \\
\text { satın alma politikasını uyarlama çalışmaları yapıyor } \\
\text { musunuz? }\end{array}$ & 9 & 60 & 6 & 40 \\
\hline $\begin{array}{l}\text { 19. Son } 3 \text { yılda başarılı bir şekilde geri dönüştürülmüş } \\
\text { ürün ve bunların ağırlıklarının kaydını tutuyor } \\
\text { musunuz? }\end{array}$ & 7 & 46,7 & 8 & 53,3 \\
\hline $\begin{array}{l}\text { 20. Geri dönüşüm firmasından herhangi bir ürün aldınız } \\
\text { mı? }\end{array}$ & 5 & 33,3 & 10 & 66,7 \\
\hline $\begin{array}{l}\text { 21. Son } 3 \text { yılda bulaşıcı olmayan materyallerin kaydını } \\
\text { tuttunuz mu? }\end{array}$ & 9 & 60 & 6 & 40 \\
\hline
\end{tabular}


Katılımcıların "Sözleşmede ve iş tanımında, atık toplama personelinizin toplama sırasında kişisel koruyucu donanım (eldiven, maske, kiyafet vb.) giymesini zorunlu kiliyor musunuz?" sorusuna verdikleri cevaplar değerlendirildiğinde, $\% 100$ 'ü evet $(n=15)$ cevabını vermişlerdir. Katılımcıların "Satın alma politikanıza, daha güvenli ve çevre dostu ürünler satın almayı bir kural haline getiriyor musunuz?" sorusuna verdikleri cevaplar değerlendirildiğinde ise $\% 66,7$ 'i evet $(\mathrm{n}=11)$ cevaplarını vermişlerdir (Tablo 5).

Katılımcıların "İş sözleşmelerinizde atık toplama işlemlerinde personelinizin bulaşıcı hastalıklara (Hepatit B vb.) karşı aşılanmasını zorunlu k1liyor musunuz?" sorusuna verdikleri cevaplar, \%100,0'ü evet $(n=15)$ cevabını vermişlerdir. Katılımcıların "Kesici ve delici tıbbi atık kutuları ile tıbbi atık torbalarının en fazla $3 / 4$ oranında olmasina dikkat ediyor musunuz?" sorusuna verdikleri cevaplar değerlendirildiğinde, \%100,0'ü evet $(n=15)$ cevabını vermişlerdir (Tablo 5).

Kat1lımciların "Tibbi atıklar ile evsel nitelikli atıkların aynı araca yüklenmemesine ve birlikte taşınmamasına dikkat ediyor musunuz?" sorusuna \%100,0 evet $(n=15)$ cevabını vermişlerdir (Tablo 5).

Katılımcıların "Kurumdaki atık miktarına ilişkin tutulan raporları yılsonunda valiliklere bildiriyor musunuz?" sorusuna verdikleri cevaplar değerlendirildiğinde, \%66,7'si evet $(\mathrm{n}=10)$ cevabını vermișlerdir. Katılımcıların "Evsel ve tıbbi atık depo kapıları kullanımları dışında daima kapalı ve kilitli tutulmasını kontrol ediyor musunuz?" sorusuna verdikleri cevaplar değerlendirildiğinde, \%100'ü evet $(n=15)$ Katılımcıların "Evsel atık içeriklerini kontrol eder misiniz?" sorusuna verdikleri cevaplar değerlendirildiğinde, \%86,7'ü evet $(n=13)$ cevabını vermişlerdir. Katılımcıların "Renk kodlu atık ayırma kılavuzu gibi materyaller kullanıyor musunuz?" sorusuna verdikleri cevaplar değerlendirildiğinde, $\% 80,0$ '1 evet $(\mathrm{n}=12)$ cevabını vermişlerdir (Tablo 5).

Katılımciların, "Hastane atıklarını azaltmak için hastanenize uygun bir satın alma politikasını uyarlama çalışmaları yapıyor musunuz?" sorusuna verdikleri cevaplar değerlendirildiğinde, \%60,0'1 evet $(n=9)$ cevabını vermişlerdir. Katılımcıların "Son 3 yılda başarılı bir şekilde geri dönüştürülmüş ürün ve bunların ağırlıklarının kaydını tutuyor musunuz?" sorusuna verdikleri cevaplar değerlendirildiğinde, $\% 46,7$ evet $(n=7)$ cevabını vermişlerdir. Katılımcıların "Geri dönüşüm firmasından herhangi bir ürün aldınız mı?" sorusuna verdikleri cevaplar değerlendirildiğinde, $\% 33,3$ 'ü evet $(n=5)$ cevabını vermişlerdir. Katılımcıların "Son 3 yılda bulaşıcı olmayan materyallerin kaydını tuttunuz mu?" sorusuna verdikleri cevaplar değerlendirildiğinde, $\% 60,0$ '1 evet $(n=9)$ cevabını vermişlerdir (Tablo 5).

Cansaran 2010'da yapmış olduğu bir çalışmada katılımcıların \%85'i kurumlarının tıbbi atık uygulamalarının yeterli olduğu düşüncesi bulunmuştur. Bunun sebebi ise hastane yönetiminin tıbbi atıklar konusunda duyarlı davrandığına ve personelin gerekli tedbirleri aldığına kanaat getirdiği düşünülmüştür. ${ }^{19}$ Çalışmamızda ise; 'Hastanenizin atık yönetim çalışmalarını yeterli buluyor musunuz?' sorusuna $\% 54,2$ 'si evet, $\% 45,8$ 'i ise hayır cevabını vermiştir. $\mathrm{Bu}$ konuda katılımcıların büyük çoğunluğu hastanedeki atık çalışmalarını yeterli bulur iken azımsanmayacak oranda katılimc yetersiz bulmuştur. Bunun sebebi hastanelerin yapmış olduğu atık yönetim çalışmalarının tüm personel tarafindan benimsenmediği düşüncesine varılmıştır.

Gerçek 2016'da gönüllü üniversite öğrencilerine yapmış olduğu çalışmada çevre etiği algilarının cinsiyet ile arasında anlamlı bir fark olmadığını saptamıştır. Gerçek'in yapmış olduğu çalışmada cinsiyete göre anlamlı bir farklılığın ortaya çıkmaması gönüllü öğrencilerin alg1 biçimleri ve sosyal çevrelerinden kaynaklandığını düşündürmektedir. ${ }^{20}$ Çalışmamızda da sağl1k personellerinin atık farkındalık ve tutum sonuçlarında cinsiyet ile anlamlı bir farklılık bulamamıştır. Bunun sebebinin de katılımcıların farklı sosyal çevrelere sahip olduğu düşünülebilir. 
Madhukumar ve Ramesh 2012'de yapmış olduğu doktorlar, hemşireler, laboratuvar teknisyenleri ve temizlik personellerini kapsayan çalışmada, katılımcıların birçoğunun eğitim programlarının uygulanmasında ve katılımında çok istekli olmadığ1 bulgusu ile karşılaşmıştır. ${ }^{21} \mathrm{Bu}$ sonuç katılımcıların eğitim konusunun fazladan bir iş olarak görmesinden kaynaklanmıştır. Çalışmamız da aynı yönde 'Kurumunuza afetlerde atık yönetim çalışması içerikli eğitim talebinde bulunuyor musunuz?' sorusuna cevap olarak \%51,7 hayır cevabı vermiştir. Bunun sebebinin ise katılımcıların kurum içi yapılan eğitimleri ekstra bir yük olarak görmesinden dolayı istekli olmadıkları düşünülmektedir.

Desa ve arkadaşları 2010'da üniversite öğrencilerini kapsayan bir çalışma yapmıştır. $\mathrm{Bu}$ çalışmanın sonucunda, çok sayıda öğrenci katı atık yönetimi ile ilgili bilgiye sahip olsa da, tutumları tutarsız olduğu sonucuna varılmıştır. $\mathrm{Bu}$ çalışmanın sonuçları, öğrencilerin yarısından fazlasının katı atık yönetimine karşı olumsuz tutumları olduğunu göstermiştir. ${ }^{22}$ Çalışmamızda da aynı doğrultuda, katılımcıların farkındalık düzey ortalamaları ile tutum düzey ortalamaları tutarsızdır. Katılımcıların farkındalık düzeyi puan ortalamaları yüksek derecede iken, tutum düzeyi ortalamaları orta düzeydedir. Bunun sebebi ise sahip olunan farkındalık düzeyinin davranışa geçirilmesi konusunda eksikliklerin olduğu ve hastane atık yönetimi çalışmalarının bu konuda yetersiz kaldığ düşünülebilir.

Barr ve arkadaşları 2003'te evsel atıkları geri dönüştürmeye yönelik tutum üzerine yapmış olduğu araştırmada; geri dönüşüme daha fazla istekli olanların, atık sorunları ve atık konusundaki sorumlulukları ile ilgilenme derecelerine göre olumlu yönde farkl1lık gözlenmiştir. Ek olarak, atık yönetim sisteminin uygulanabilirliği ve atık noktalarına erişim kolaylığ davranışları üzerinde olumlu tutum sergileyecekleri yönünde bulgular elde etmiştir. ${ }^{23}$ Çalışmamızda ise 'Hastaneniz atıklar için kapsamlı bir geri dönüşüm politikası benimsemeye karar verirse, bu yaklaşımı destekleyecek misiniz?' sorusuna $\% 40,4$ katıliyorum ve $\% 42,1$ kesinlikle katılıyorum cevapları elde edilmiştir. $\mathrm{Bu}$ sonuçlardan yola çıkarak hastane yöneticilerinin ileriye dönük geri dönüşüm içerikli bir atık yönetim politikasında başarılı olabileceği öngörülmektedir. Atık depolama noktalarının yerleşim alanlarına uzak noktalarda ve uygun koşullarda depolanması sağlanması, periyodik olarak kontrol ve ölçümlerin yapılması, alınan önlemlerin yetersiz gelmesi durumuna karşın ek önlemler belirlenmesi önerilmektedir. Atık depolama noktalarının herhangi bir afetten etkilenmeyecek mevkilerde konuşlanması, konuşlanacak bölgelerin bu şekilde afetlerden zarar görmeyecek alanlara inşa edilmesi önerilmektedir.

Şahin ve Hatunoğlu 2016'da üniversite personeli, lisans ve lisansüstü öğrenciler ile rektörlük personeli, rektör ve yardımcılarına bir araştırma yapmıştır. Katılımcılar geri dönüşümün önündeki engellerin geri dönüşüm noktalarının nerede olduğunun bilinmemesi, bu noktalara atığ 1 ulaştırmanın zor olması ve geri dönüşüme destek verme düşüncesinin akıllarına gelmemesi gibi sebepleri dile getirmiştir. ${ }^{24}$ Çalışmamızda ise sağlık personellerinin geri dönüşümü engelleyen faktörler arasında ise, $\% 47,8$ atık bilinci ve eğitimi eksik personel, $\% 18$ maddi güçlükler ve \%14,9 ile yönetimsel problemler olabileceği sonucuna varılmıştır. Kurum personellerine atık yönetimi hakkına bilinç, farkındalık ve tutum becerileri kazandırılarak atık yönetimi sistemine doğrudan dâhil edilmesi sağlanmasi önerilmektedir. $\mathrm{Bu}$ sayede gerçekleştirilen uygulamaların farklı bakış açılarıyla değerlendirilmesi sağlanabilir. Bunun sonucunda da mevcut atık yönetimi sisteminin eksikliklerinin belirlenmesi ve sistemin iyileştirilmesi daha etkin bir şekilde gerçekleştirilmesi sağlanabilir. 


\section{SONUÇ VE ÖNERILER}

Katılımcıların farkındalık düzeyi puan ortalamaları, çalışma sürelerine göre değerlendirildiğinde anlamlı fark bulunmuştur. Çalışma süresi 21 yıl ve üzeri olan katılımcıların farkındalık düzeyi puan ortalamaları diğer katılımcılara göre daha yüksektir. Personelin farkındalık düzeyinin eğitimler ile arttırılması, bu sayede mesleğe yeni başlayan personelin daha bilinçli ve doğru uygulamalar ile bilgisinin pekiştirilmesi önerilmektedir. $\mathrm{Bu}$ bilgi pekiştirmesi, afet anında tüm personelin doğru hareket etmesine, afet sürecinde atıkların kaynağında azaltılması adımına ve dolaylı olarak da afetlerin yönetiminde yer alan her bir aşamada daha aktif bir şekilde rol almasını sağlayabilir.

Katılımcıların farkındalık düzeyi puan ortalamaları, eğitim durumlarına göre değerlendirildiğinde doktora eğitim durumuna sahip olan katılımciların farkındalık düzeyi puan ortalamaları diğer katılımcılara göre daha yüksektir. Farkındalık düzeyindeki mezuniyet durumundan kaynaklanan farklılıklar hizmet içi eğitimler ile eşit duruma getirilmesi önerilmektedir. $\mathrm{Bu}$ nedenle hizmet içi eğitimlerin arttırılması, personelin aynı bilgi düzeyine ulaşması sağlanması ve bu uygulamalar sayesinde ekip içi uyum ve motivasyon seviyesinin yükseltilmesi mümkündür. Bu sayede zor olan atık yönetiminin yönetilmesinde kolaylık sağlanabilir. Personellerin atık yönetimi konusundaki bilgi, tutum ve farkındalık seviyesinin eşit değerlerde ve yüksek düzeyde olması; en alt basamakta ekip içi uyum, en üst basamakta ise atık yönetimi sisteminin iyileştirilmesi sağlanabilir. Bu nedenle tüm personelin beceri düzeylerinin aynı ve yüksek seviyede olması için farklı uygulamalar yapılması önerilmektedir.

Katılımcıların farkındalık düzeyi puan ortalamaları, atık yönetimi eğitim durumlarına göre değerlendirildiğinde atık yönetimi eğitimi alan katılımcıların, eğitimden dolayı atıkların tehlikeleri konusunda daha bilinçli olduğu düşünülmektedir. Personele atık yönetimi gibi konularda eğitimler ile atıkların tehlike boyutunu anlamaları ve bu konuda bilinç kazanmaları için uygulamalı faaliyetler ile beceri kazandirılması önerilmektedir. Yaşanacak herhangi bir afetten sonra ikincil bir afete neden olabilecek risklerin hazırlık çalışmaları ile önlenmesi mümkün olabilir.

Katılımcıların farkındalık düzeyi puan ortalamaları, afet eğitimi durumlarına göre değerlendirildiğinde afet eğitimi alan katılımcıların farkındalık puan düzeyi ortalamaları diğerlerine göre daha yüksektir. $\mathrm{Bu}$ durum afet eğitimi alan kişilerin, atığı afet ya da acil durum boyutuna ulaşabilecek bir risk olarak düşünmesi olabileceği kanısına varılmıştır. Uygun yönetilemeyen atıkların afete sebep olabilecek bir risk olarak bakış açısının kazandırılması, afetten sonraki süreçlerde yapılacak faaliyetlerin uygulanabilirlik düzeyinin seviyesini arttırılabilir. Bu nedenle, personele bu bakış açısının kazandırılması ve becerilerinin geliştirilmesi önerilmektedir. Bu sayede afet sonrası görev ve sorumluluklarının farkında olan personelin dâhil olduğu atık yönetimi sisteminin işlevselliği arttırılabilir.

Katılımcıların tutum düzeyi puan ortalamaları yaş durumlarına göre değerlendirildiğinde katılımcılar arasında tutum düzeyi puan ortalamaları en yüksek olan 18-30 yaş grubudur. Bunun sebebi bu yaş grubunun diğer yaş gruplarına kıyasla dijital ortamları daha etkin kullanarak bilgiye daha kolay ulaşması bu sebeple çevresel olarak daha dikkatli ve güncel değişikliklerden daha çabuk haberdar olduklarından dolayı tutum düzeylerinin yüksek olduğu düşünülmektedir. Personelin atık konusunda tutum düzeylerini arttırmaya yönelik tatbikat, etkili atık yönetim planları ve projeleri gibi uygulamalı faaliyetler gerçekleştirilmesi önerilmektedir.

Ulusal, bölgesel, yerel ve kurumsal afet planlarında atık gibi ikincil afetlere neden olabilecek olgulara karşı ek önlemler alınması önerilmektedir. $\mathrm{Bu}$ sayede afet sonrasında oluşabilecek ek kayıpların önüne geçilip; ekonomik, sosyal, psikolojik ve çevresel kayıpların etki düzeyi düşürülebilir.

Atık yönetimi ve afet atığı konularında daha fazla çalışma yapılması özellikle de 
afetlerde etkin olarak rol alanların bu konuda ki hazırlık, farkındalık düzeyleri incelenmesi ve sonucunda da yapılan araştırmalar neticesinde iyileştirmeler yapılmasını ve imkânların sağlanması önerilmektedir.

Atık yönetimi sadece hukuki olarak ele alınan bir olgu olarak yürütülmemelidir. Personellerin ve yöneticilerin atı yönetimindeki tutumları daimi olmalı yani bu tutumları davranış tarzı haline getirilmesi gerekir. Bunun için ise yöneticilerin personelleri atık yönetimi konusunda teșvik edici uygulamalar kullanarak motive edip atık yönetimine dâhil etmesi önerilmektedir. Bünyesinde atık üretimi yapan kurum ve kuruluşların, atık yönetimi sisteminin geliştirilmesi, kontrol altında tutulması, uygun yöntemler ile depolama, enerji kazanımı, geri dönüşüm ve bertaraf uygulamalarını gerçekleştirilmesi sağlanmalıdır. Ayrıca atıkların bir afet boyutuna ulaşmasına veya afetler sonucunda ikincil bir afete sebebiyet vermeyecek şekilde atık yönetimi sisteminin sürekliliğinin, güncelliğinin ve esnekliğinin sağlanması önerilmektedir.

Afete müdahale uygulamaları sonucunda ortaya çıkacak atıkların yönetim planlaması hazırlık evresinde yapılması, uygulanabilirliğinin denetlenmesi, uygulanabilirliği düşük olan sistemlerin güçlendirilmesi önerilmektedir.

Kurum ve kuruluşların, atık yönetimi bazında yasal mevzuat gerekliliklerine uygunluğu denetlenmesi, düşük düzeyde olan kurumların atık yönetimi sistemlerinin güçlendirilmesi için ilgili kurumlar tarafından destek verilmesi önerilmektedir. Bu sayede mevcut sistemlerin afetlerden zarar görebilirlik seviyesinin makul seviyelere gelmesi sağlanabilir.

Atıkların sahip olduğu maddelerden dolayı yayabileceği biyolojik, kimyasal ve radyolojik etkiler gibi zarar veren etkiler atık yönetimi sistemine dâhil edilerek, alınacak önlemlere bu tehlikelerin de önlenmesi hedeflenmeli yani kaynağında yok etme gibi atık yönetimi davranışı sergilenmelidir.

Afet sürecinde insan cesetlerinin ve vücut parçalarının sahip oldukları tehlikeleri, çevre ve halk sağlığı üzerine olumsuz etkileri göz önüne alındığında afet atığı olarak ele alınabilir. Fakat insan cesetleri afetin olduğu bölgenin kültürel ve dini yapılarına uygun şekilde bertaraf edilmesi önerilmektedir.

Hastaneler sağlık hizmetleri vermektedirler; bu sebeple ürettikleri atıklar sebebi ile iş sağlığ 1 , halk sağlığ ve çevre sağlığı üzerine olumsuz etki oluşturarak önemli bir risk haline gelmektedir. Yapılacak planlama aşamalarında bu riskin önlenmesi veya meydana gelmesinin engellenmesi için gerekli adımlar atılması önerilmektedir.

$\mathrm{Bu}$ araștırma ile literatürde hastanelerin olağan ve olağan üstü durumlarda atık yönetimi konusunda eksiklerini gidermek amaçlanmıştır. Fakat yapılan bu çalışma yerel bir düzey olarak ele alındığından literatürdeki eksiklikleri kapatmak için yeterli olmayacağ için afetlerde atık yönetimi konusunda çalışmalar yapılması önerilmektedir
1. Giusti, L. (2009). "A Review of Waste Management Practices and Their Impact on Human Health". Waste Management, 29 (8), 2227-2239.

2. Hoornweg, D. and Bhada-Tata, P. (2012). What A Waste: A Global Review of Solid Waste Management Washington: The World Bank.

3. Brown, C, Milke, M, Seville, E. (2011). "Disaster Waste Management: A Review Article”. Waste Management, 31 (6), 1085-1098.

4. UNEP and OCHA (2013). Disaster Waste Management Guidelines. Switzerland: UNEP/OCHA Environment Unit.

5. Stantec. (2017). Report Disaster Waste Management Planning. New Zealand.
6. Chartier, Y, Emmanuel, J, Pieper, U, Pruss, A, Rushbrook, P, Stringer, R, Townend, W, Wilburn, S. and Zghondi, R. (2014). Safe Management of Wastes From Health-Care Activities. Switzerland: World Health Organization.

7. Brown, C. and Milke, M. (2009). Planning for Disaster Debris Management. University of Canterbury, Department of Civil \& Natural Resources Engineering.

8. Asari, M, Sakai, S, Yoshioka, T, Tojo Y, Tasaki, T, Takigami, H, Watanabe, K. (2013). "Strategy for Separation and Treatment of Disaster Waste: A Manual for Earthquake and Tsunami Disaster Waste Management in Japan". Journal of Material Cycles and Waste Management, 15 (3), 290-299. 
9. United Nations Environment Programme (2008). Disaster Waste Management Mechanism a Practical Guide for Construction and Demolition Wastes in Indonesia. Indonesia: Unep Publicated.

10. East Gippsland Shire Council. (2016). East Gippsland Disaster Waste Management Plan Version 1.1.

11. Sangeeta, S, Pangam, P, Giriyan, A. (2008). "Green Reconstruction of the Tsunami-affected Areas in India Using the Intagrated Coastal Zone Management Concept". Journal of Environmental Management, 8 (1), 14-23

12. UNHRC. (2018). Emergency Waste Management Standard Emergency Handbook. (https://emergency.unhcr.org).

13. Reinhart, D. And Mccreanor, P. (1999). Disaster Debris Management - Planning Tools. USA: Environmental Protection Agency.

14. Aydoğdu Çobanoğlu, N. ve Bezen İ. (2019). Tibbi Atıkların Olușturduğu Sorunların Cevre, Sağlık ve Etik Açısından İncelenmesi Ankara T.C. Kültür ve Turizm Bakanlığı Atatürk Kültür, Dil ve Tarih Yüksek Kurumu.

15. Aydemir, İ. (2017). “Türkiye'de Çevre Bilinci Kapsamında Tibbi Atik Üretim Süreçleri ve Yönetimi”. Bingöl Üniversitesi Sosyal Bilimler Enstitüsü Dergisi, 7 (13), 295 311.

16. Pruss, A, Giroult, E, Rushbrook, P. (1999). Safe Management of Wastes From Health-Care Activities. Genova: World Health Organization.

17. Eigitait, Y. (2013). Staff Perceptions and Practice for Hospital Waste Management with Reference to Recycling in the UK versus Libya, a Comparative Study. Liverpool John Moores University, Doctoral Dissertation, England.
18. Seçer, İ. (2015). SPSS ve LISREL ile Pratik Veri Analizi. Ankara: Anı Yayıncılık.

19. Doğan Cansaran, D. (2010). Çevre-Sağlık İlişkis Ekseninde Tıbbi Atık Yönetimi. Ankara Üniversitesi Sosyal Bilimler Enstitüsü, Yayımlanmamış Doktora Tezi, Ankara.

20. Gerçek, C. (2016). "Üniversite Öğrencilerinin Çevre Etiğine Yönelik Algıları". Elektronik Sosyal, Bilimler Dergisi, 15 (59), 1100-1107.

21. Madhukumar, S. and Ramesh, G. (2012). "Study About Awareness and Practices About Health Care Wastes Management Among Hospital Staff in A Medical College Hospital, Bangalore". International Journal of Basic Medical Science, 3 (1), 7-11.

22. Desa, A, Bayahabd, K, Yusooff, F. (2011). "A Study On Knowledge, Attidues, Awareness Status and Behaviour Concerning Solid Waste Management". Procedia Social and Behavioral Sciences, 18, 643-648.

23. Barr, S, Ford, N, Gilg, A. (2003). "Attitudes Towards Recycling Household Waste in Exeter, Devon: Quantitative and Qualitative Approaches". The International Journal of Justice and Sustainability, 8(4), 407-421.

24. Şahin, S. ve Hatunoğlu Z. (2016). "Geri Dönüşüm Sistemlerine Yönelik Algı Düzeyi, Finansmanı ve Muhasebeleştirilmesi: Kahramanmaraş Sütçü İmam Üniversitesi Örneği”. Ekonomik ve Sosyal Araştırmalar Dergisi, 12 (2), 73-93. 